\title{
Speaking from other demonic bases of partiality
}

\author{
Sneha Krishnan \\ Associate Professor in Human Geography \\ School of Geography and the Environment, University of Oxford \\ Sneha.krishnan@ouce.ox.ac.uk
}

\begin{abstract}
As Simandan argues, partiality and contingency are key to a politically-attuned human geography. My comment takes the author up on his suggestion that commentators examine the political implications of his framework. Critically I use Sylvia Wynter's analytic of 'demonic ground' to critique Simandan's 'demonic geography' that underlies the epistemic framework he presents in this paper. In doing so, this comment focuses on the author's conceptualisation of intersectionality and diversity, arguing instead for a more fundamental critique of the geopolitical location of posthumanist thought itself.
\end{abstract}

Keywords: Sylvia Wynter, Race, Decolonial Theory, Intersectionality, Diversity 
What does it mean to be human and to engage in a project of knowing? Dragos Simandan's paper addresses this debate by taking forward the anti-humanist project he has previously articulated as a 'demonic geography' (Simandan, 2017). His work elaborates a materialistic basis for ethical being, rethinking the human subject as 'soulless' or a mechanistic assemblage of neurotransmitted material. In this new paper, Simandan develops this framework further, proposing four epistemic gaps - suggesting a multiplicity of possible worlds, and the incompleteness of witness, narrative and memory - that explain the partiality of all knowledge. The paper explicitly seeks to develop on feminist and queer scholarship developed within a posthumanist framework - primarily the work of Donna Haraway (1988) - to critique freewill-bearing and sovereign subjectivity.

My comment on this paper picks up on a question that Simandan himself raises throughout his paper: that of the framework's political implications. In particular, he calls for an examination of how the paper's framework might address 'how the four gaps are political and how different subject positions in networks of power intersect with one another to produce different experiences and perceptions of these gaps' (p.6). Reading with Simandan's critique that a humanist framework is limiting in this endeavour, I counterpoise his anti-humanist geography with the interventions of black feminist scholars, prominently Sylvia Wynter (1990) and Katherine McKittrick (2006), who also propose the 'demonic' as an analytic. In doing so, I explore how Black posthumanist thought problematises questions about intersectionality and positionality through a critique of the imperialist bases of epistemic thinking on the human subject. The main contribution that this latter debate has made to posthumanist thinking is to interrogate race as 'a constitutive category in thinking about the parameters of humanity' (Weheliye 2008, 321). In this, it articulates a genealogy of thought on the human that speaks not so much to Foucault's critique but to Aimé Césaire's interrogation of blackness at the limits of human subjectivity within imperial thought (Césaire, 2001). Further, this debate poses race 
- always intertwined with gender and sexuality - not as a problem of social difference but as integral to articulations of the human as 'Man'.

\section{Another Demonic Locus of Partiality}

By 'demonic', Sylvia Wynter refers to 'perspectives that reside in the liminal precincts of the current governing configurations of the human as man in order to abolish this figuration and create other forms of life' (Weheliye, 2008: 323). In articulating a 'demonic ground' for her philosophy, Wynter proposes to de-centre the human as Man, and work instead from the margins: focusing on subjects who constitute the limits of what it means to be human. In this, she too sets out an explicitly anti-humanist project albeit one that makes visible the Eurocentrism and histories of imperialism at the heart of the string of connections between the human as 'Man', and the attribution of this subject with free will, as well as cognitive capacities for sovereign subjectivity (Wynter 1990, see also Weheliye 2014). Speaking within this 'other' genealogy of the posthuman, the 'demonic' as Sylvia Wynter conceptualises it - and for geographers, as it is developed in the work of Katherine McKittrick (2006) - also questions free-will bearing sovereign human subjectivity. Drawing as does Simandan from debates on cognition, Wynter, in her conception of the 'demonic' locates cognition outside 'the always non-arbitrary pre-prescribed' (cited in McKittrick, 2006: xxv).

The absence of this conception of the 'demonic' from Simandan's discussion both in this paper and in his previous examination of some of these themes (Simandan, 2017) might be attributable to Wynter's reception largely as a Caribbean cultural theorist. However, the mainstay of posthumanist scholarship - driven by a genealogy that draws from Foucault's call to denaturalise the category of 'Man' (Foucault, 2005 [1966]) and speaks through Donna Haraway and Bruno Latour - rarely engages the critique of Eurocentric 'Man' as the paradigmatic human subject in the work of Black social theorists, and particularly black feminist and queer scholars. Crucially, as Zakiyyah Iman Jackson $(2015,276)$ points out, the 
silence in posthumanist and new materialist literatures on race '[persists] even despite the reach of antiblackness into the nonhuman - as blackness conditions and constitutes the very nonhuman disruption and/or displacement they invite'. In other words, then, this critical scholarship pushes for an answer to the 'so what' question that hovers over Simandan's framework, and in doing so, problematises its assumptions on intersectionality and diversity.

This critique of his work finds some ironic resonance in Simandan's critique of academic disciplines as a site where epistemic plurality might serve to better highlight contingencies and uncertainties over firmly drawn boundaries. Engagement with the black feminist and queer thought on race and posthumanism that I have outlined might allow for Simandan's framework to loop back on itself and question the framework of diversity on which it relies for this project of unsettling.

\section{Intersectionality and the 'Where' of the Posthuman}

Most usefully for geographers, black feminist scholarship on the human subject asks if the 'post' in post-human should signify not so much a temporal location after humanism but instead a geopolitical location outside of the West (Jackson, 2015). To think otherwise, this work provocatively argues, might be to return to a Eurocentric transcendentalism that posthumanism might otherwise claim to challenge (Wynter 2003). This would suggest further that while scholars like Haraway unsettle 'Man' as sovereign subject and god-trick-performer, they fail to undo the primacy of secularism inherent in Enlightenment thought that undergirds the ontology of 'Man'. Indeed, an explicitly disenchanted view of the human is central to Simandan's discussion of cognition and perception in the epistemic framework he puts forward (both in this paper and in Simandan 2017).

A debate on enchantment and modernity tied inextricably to the question of location is key to Wynter's decolonial analytic of the demonic (Wynter, 1995) in which she posits disenchantment as the closing-off of contingency: of conditions of cognition and speech 
beyond what is made legible and possible within Eurocentric scientific logic. This is not so much to critique secular modernity as opposed to spiritual or transcendental experience but to make visible the discursive bases of its own conceptions of reality and possibility. Reading this debate on the terms of human cognition by building dialogue between Darwin and Freud in early twentieth century scientific debates on the human subject, Michael Lundblad (2013) further shows that an evolutionary ethic pervaded scientific discourse in this period. Cognition and speech beyond the realm of what was socially legible was widely relegated to the limits of humanness. In this reading, race and gender are thus not so much positional locations that might shape perception upon a shared cognitive ground but fundamentally shape the terms on which perception is made possible and socio-politically legible (see also Seshadri 2012).

In the reading above, then, femaleness and queerness, as much as race, are not diverse perspectives that might find expression in a multiplicity of standpoints, each of which is partial but instead constitutive of epistemic ground from which critique is made possible (Somerville 1994, 2000). In this, Wynter's demonic unsettles the imperialist-racial underpinnings of liberal humanism 'at the juncture of the culture and biology feedback loop' (Weheliye, 2008: 323). Most significantly to this paper, it pushes for a rethinking of what Simandan calls the 'pragmatic reality of diversity' (p.28), positing instead that these differences are integral to the articulation of epistemic projects that make claims to universality. So even as we might demonstrate that indeed all knowledge - scientific and otherwise - is partial, Wynter's 'demonic' forces a questioning of how the epistemic ground from which this questioning occurs - i.e. scientific discourse about cognition - is wrought within an imperial history that has accorded humanness differentially (see also Rutsky 2007).

\section{Conclusion}

This paper has argued that while Simandan's framework of epistemic gaps proposes an important pragmatic way of operationalising Haraway's concept of partiality, its conception of 
partiality and diversity do not engage the significant critiques of race and gender as social difference in the work of Black feminist scholars. By drawing on Sylvia Wynter's analytic of the 'demonic', I have laid out an 'other' - a word that I have used in quotes throughout to signal its location within a geopolitical and semiotic field of imperial power - genealogy of posthumanist thought that also seeks to unsettle the figure of the sovereign, self-contained and free-will-bearing human subject. This scholarship advances in this project through a decolonial praxis that seeks to problematise the colonial underpinnings of the category of Man - as a genre, as Sylvia Wynter reminds us - as imbricated in the ongoing logic slavery and imperialism.

To conclude then, one of the contributions that Simandan outlines for his paper is the argument that lay knowledge is as much partial as scientific knowledge. For this, he offers evidence from Social Psychological scholarship that 'lay' people tend to see their own partial and contingent experiences as universal. We might trouble this reading as well through black feminist critique that asks how imperial discourse founded on racial difference shapes the socio-political legibility of speech as 'human'. This scholarship would then ask of Simandan's paper how it might re-examine the scientific and legal discourse on which cognition is made socially legible in its conception of 'lay' forms of knowledge.

In all, this comment has attempted to draw Simandan's paper into a debate with a significant Black feminist scholarship on the meaning of the (non)human as necessarily racial. In doing so, it has sought to problematise the paper's own engagement with the human through its reliance on a materialist anti-humanist framework, as well as engaging Simandan's call to the reader to ask how intersectional axes of power difference might be operationalised within his framework.

\section{References}

Foucault, M., 2005 [1966]. The order of things. London: Routledge. 
Haraway, D., 1988. Situated knowledges: The science question in feminism and the privilege of partial perspective. Feminist studies, 14(3), pp.575-599.

Jackson, Z. 2013. Animal: New Directions in the Theorization of Race and Posthumanism. Feminist Studies, 39(3), pp.669-685.

Jackson, Z.I., 2015. Outer Worlds: The Persistence of Race in Movement" Beyond the Human". GLQ: A Journal of Lesbian and Gay Studies, 21(2), pp.215-218.

Lundblad, M., 2013. The birth of a jungle: Animality in progressive-era US literature and culture. Oxford University Press.

McKittrick, K., 2006. Demonic grounds: Black women and the cartographies of struggle. University of Minnesota Press.

Rutsky, R.L., 2007. Mutation, history, and fantasy in the posthuman. Subject Matters, 3(2), pp.99-112.

Seshadri, K., 2012. HumAnimal: Race, law, language. University of Minnesota Press.

Simandan, D., 2017. Demonic geographies. Area, 49(4), pp.503-509.

Somerville, S., 1994. Scientific racism and the emergence of the homosexual body. Journal of the History of Sexuality, 5(2), pp.243-266.

Somerville, S.B., 2000. Queering the color line: Race and the invention of homosexuality in American culture. Duke University Press.

Weheliye, A.G., 2008. After man. American Literary History, 20(1-2), pp.321-336.

Weheliye, A.G., 2014. Habeas viscus: Racializing assemblages, biopolitics, and black feminist theories of the human. Duke University Press.

Wynter, S., 1990. Beyond Miranda's Meanings: Un/silencing the 'Demonic Ground' of Caliban's 'Woman.' In Carole Boyce Davies and Elaine Savory Fido eds. Out of the Kumbla: Caribbean women and literature, Trenton: Africa World Press: pp.355-72.

Wynter, S., 1995. The Pope must have been drunk, the King of Castile a madman: Culture as 
actuality, and the Caribbean rethinking modernity. In Alvina Ruprecht and Cecilia Taiana, eds., The reordering of culture: Latin America, the Caribbean and Canada in the hood, Ottawa: Carleton University Press: pp.17-41.

Wynter, S., 2003. Unsettling the coloniality of being/power/truth/freedom: Towards the human, after man, its overrepresentation-An argument. CR: The new centennial review, 3(3), pp.257-337. 